Ivan Đekić ${ }^{1}$

Niš, Serbia
SCIENTIFIC REVIEW ARTICLE

doi:10.5937/ekonomika1503133D

Received: April 14, 2015

Accepted: June 10, 2015

\title{
IMPROVING HUMAN CAPITAL IN SERBIA
}

\begin{abstract}
The author identifies the level of human capital development in Serbia, then he analyses the limitations of human capital development, and finally he proposes measures and activities needed for the improvement of human capital. The aim is to pave the way for human capital development in Serbia. Research uses the inductive and deductive methods, analysis and synthesis, statistical and comparative method. Human capital is viewed through four key components: education, health, work and socioeconomic environment. The level of human capital development in Serbia was identified through the prism of Human Capital Index from Human Capital Report of the World Economic Forum. Human capital development is observed in the context of economic growth speed. The conclusion of the paper is that human capital in Serbia is at a low level and that its improvement requires reform of education and health, employment growth, labour market reform and good socioeconomic environment.
\end{abstract}

Key words: human capital, education, workforce, socioeconomic environment, economic growth.

JEL classification: $\mathrm{I} 25, \mathrm{~J} 24, \mathrm{O} 15$

\section{УНАПРЕЪЕЊЕ ЉУДСКОГ КАПИТАЛА У СРБИЈИ}

\begin{abstract}
Апстракт
Аутор у раду идентификује ниво развијености људског капитала у Србији, затим анализира ограничења развоја људског капитала, а на крају предлаже мере и активности неопходне за унапређења људског капитала. Циљ рада је трасирање пута развоја људског капитала у Србији. Као методи истраживања коришћени су индуктиви и дедуктивни метод, метод анализе и синтезе, затим, статистички и компаративни метод. Људски капитал се посматра кроз четри кључне компоненте: образовање, здравље, свет рада и друштвено-економско окружење. Ниво развијености људског капитала у Србији је идентификован кроз призму Индекса људског капитала из Извештаја људског капитала Светског економског форума. Развој људског капитала се сагледава у контексту убрзања привредног раста. Закључак рада јесте да је људски капитал у Србији на ниском нивоу и да његово унапређење захтева реформу система образовања и здравства, раст запослености, реформу тржишта рада и добро друштвено-економско окружење.
\end{abstract}

Кључне речи: људски капитал, образовање, радна снага, друштвеноекономско окружење, привредни раст.

1jekic777@gmail.com 


\section{Introduction}

Human capital in economic theory is defined as a set of knowledge, skills and abilities of employees that they incorporate into production and service processes and activities of economic entities and thus contribute to the growth of labour productivity and/or quality improvement of products and services with the aim of achieving economic value. It is a concept that unifies the characteristics of capital and human factors. In fact, human capital is the quality of the workforce.

Human capital is generated through formal and informal channels. Precisely, human capital is created and developed in the first place through education, the second within the world of work, and the third within the family. The knowledge, experience and real motivation, which are developed within the family, as informal channel, determine the ability and efficiency of acquiring new knowledge and skills throughout education and work. In fact, education is the key factor in the development of human capital. In the case of formal education, which is the most important mechanism for the generation and promotion of human capital, the sphere of state primary education that determines the options and choices is of particular importance (Zubović, 2007, p. 2). Informal education is of great importance for the development of human capital in comparison to formal education. The knowledge, skills and experience are also acquired and improved through training and learning. Above all, the role of health is very important for the creation and development of human capital as well as its value and usefulness.

Human capital is one of the key factors of economic and social progress (Krstić, Backović, Džunić, M., 2012). The positive impact of human capital in economic terms is reflected in contributing to faster economic growth, increasing labour productivity and lowering unemployment (Krstić, Stanojević, 2013). People with better education have lower risk of unemployment and poverty. Economies which are with high quality workforce are more competitive. Economic development is impossible without the change in the structure and quality of the labour force because people and their competencies are key drivers of economic development.

Human capital in Serbia is inadequate both in quality and quantity. Decades of economic crisis, lack of growth and development, regression in the development as well as numerous systematic deficiencies, limitations and defects have led to massive loss of human capital. Investment in human capital, or its increase, makes sense only if there is adequate return. Otherwise, there is a loss of motivation for increasing human capital and its reduction. Education and health make a large impact on the value of human capital, but in our case they have poor performance. Human capital is also reduced due to massive long-term unemployment, bad attitude of entrepreneurs towards this form of capital and negative demographic trends.

The lack of quality workforce in Serbia and its misuse have a strong negative impact to the slow dynamics of economic growth and make it one of the basic factors of low competitiveness of the domestic economy. Therefore, the paper discusses the possibilities for improvement of human capital in Serbia, and it is preceded by analysis of state of human capital, then, understanding the factors that limit the development of human capital with the aim to provide direction for its improvement and increase, and thereby contributing to the bigger economic growth and stabilization of development. 


\section{Research methodology}

The paper will apply inductive and deductive methods, methods of analysis and synthesis, and statistical and comparative methods. Human capital is viewed through the four basic components: education, health, work and socioeconomic environment. The level of development of human capital in Serbia is observed through Human Capital Index from the Human Capital Report of the World Economic Forum, which assesses the human capital in Serbia and reviews of each of the individual components of human capital. In particular, we analyse each of the components of human capital: education, health, work and socioeconomic environment, in order to make an overview the value of human capital in Serbia through the method of synthesis. The level of development of human capital and the limits of development of human capital are observed through inductive and deductive methods, where the state of the practice leads to the general conclusions, on the one hand, and making individual conclusions on the basis of general attitude, on the other hand. The research was supported by indicators and descriptive statistics that provide insight into the situation in the field of human capital in Serbia and each of the individual components of the capital, as well as their interconnection and cause. Comparative method can be used for reviewing and comparison of the situation in Serbia and the developed countries of Europe, as to deepen knowledge about the value of domestic human capital.

Based on the results of research on the development of human capital in Serbia and limitations for its future development, the author provides recommendations and guidelines and makes conclusions for the improvement of human capital, which certainly requires the use of inductive and deductive methods, and method of synthesis.

\section{Human capital in Serbia - the level and characteristics}

The development of human capital in Serbia is viewed through the prism of Human Capital Index of the World Economic Forum. Index of human capital includes three key areas of human capital: education, health and labour - pillars 1, 2, and 3, or their contribution to the development of human capital. In addition, the value of human capital is determined by physical, social and economic environment - pillar 4: environment, which determines whether the human skills and knowledge are valued in the right way and how they are useful and profitable.

Table 1 Index of Human Capital (2013)

\begin{tabular}{|l|c|c|c|}
\hline \multirow{2}{*}{} & \multicolumn{2}{|c|}{ Serbia } & OECD \\
\cline { 2 - 4 } & Rank/122 & Score & Score \\
\hline Index of Human Capital & 85 & -0.343 & 0.713 \\
\hline Pillar 1: Education & 59 & 0.053 & 0.766 \\
\hline Pillar 2: Health and Wellness & 52 & 0.115 & 0.599 \\
\hline Pillar 3: Workforce and Employment & 118 & -0.945 & 0.586 \\
\hline Pillar 4: Enabling Environment & 89 & -0.596 & 0.899 \\
\hline
\end{tabular}

Source: Human Capital Index, (2013), World Economic Forum, p. 19 \& 446. 
According to the Index of human capital, Serbia got mark -0.343 and it was on 85th place out of 122 countries in 2013, and it indicates a low level of human capital development. The rating is indicative -0.343 , especially when it compares with grade 0.713 for OECD countries, where human capital is the highest quality and most competitive. Observed by the pillars of the Index of human capital, the situation in Serbia is the best in the health pillar, it is poorer in education pillar, while it is poor in the enabling environment pillar, and the very poor in the workforce pillar. All pillars of Index of human capital show bed marks.

Table 2 presents the indicators within the pillars of the Index of human capital for a more detailed overview of the situation in individual areas.

Table 2 Indicators of Human Capital (2013)

\begin{tabular}{|c|c|c|c|c|c|}
\hline & $\begin{array}{c}\text { Rank/ } \\
122 \\
\end{array}$ & Score & Value & $\begin{array}{l}\text { Value } \\
\text { min. }\end{array}$ & $\begin{array}{l}\text { Value } \\
\text { max. }\end{array}$ \\
\hline \multicolumn{6}{|l|}{ Pillar 1: Education } \\
\hline $\begin{array}{l}\text { Access } \\
\text { - Primary enrolment rate (\%) } \\
\text { - Secondary enrolment rate (\%) } \\
\text { - Tertiary enrolment rate (\%) } \\
\text { - Education gender gap }\end{array}$ & $\begin{array}{l}75 \\
23 \\
43 \\
55\end{array}$ & $\begin{array}{l}0.131 \\
0.787 \\
0.373 \\
0.452\end{array}$ & $\begin{array}{c}94 \\
90 \\
50 \\
0.993\end{array}$ & $\begin{array}{c}58 \\
16 \\
1 \\
0.645\end{array}$ & $\begin{array}{c}100 \\
100 \\
103 \\
1.000\end{array}$ \\
\hline $\begin{array}{l}\text { Quality } \\
\text { - Internet access in schools } \\
\text { - Quality of the education system } \\
\text { - Quality of primary schools } \\
\text { - Quality of math \& science education } \\
\text { - Quality of management schools }\end{array}$ & $\begin{array}{c}74 \\
96 \\
68 \\
48 \\
100\end{array}$ & $\begin{array}{r}-0.329 \\
-0.770 \\
-0.201 \\
0.306 \\
-0.808\end{array}$ & $\begin{array}{l}3.91 \\
3.11 \\
3.72 \\
4.33 \\
3.62\end{array}$ & $\begin{array}{l}1.64 \\
1.99 \\
1.97 \\
1.88 \\
2.29\end{array}$ & $\begin{array}{l}6.64 \\
5.98 \\
6.82 \\
6.29 \\
6.09\end{array}$ \\
\hline $\begin{array}{l}\text { Attainment } \\
- \text { Primary education attainment (\%, popul. age } \\
25+\text { ) } \\
\text { - Secondary education attainment (\%, popul. age } \\
25+\text { ) } \\
\text { - Tertiary education attainment (\%, popul. age } 25+\text { ) }\end{array}$ & $\begin{array}{l}- \\
22 \\
49\end{array}$ & $\begin{array}{c}- \\
0.883 \\
-0.235\end{array}$ & $\begin{array}{c}- \\
86 \\
16\end{array}$ & $\begin{array}{l}5 \\
2 \\
0\end{array}$ & $\begin{array}{c}100 \\
100 \\
44\end{array}$ \\
\hline \multicolumn{6}{|l|}{ Pillar 2: Health and Wellness } \\
\hline $\begin{array}{l}\text { Survival } \\
\text { - Infant mortality (per } 1000 \text { live births) } \\
\text { - Life expectancy } \\
\text { - Survival gender gap }\end{array}$ & $\begin{array}{l}35 \\
59 \\
81\end{array}$ & $\begin{array}{l}0.697 \\
0.177 \\
-0.060\end{array}$ & $\begin{array}{c}6 \\
74 \\
0.970\end{array}$ & $\begin{array}{c}2 \\
50 \\
0.920\end{array}$ & $\begin{array}{c}98 \\
83 \\
0.980\end{array}$ \\
\hline $\begin{array}{l}\text { Health } \\
\text { - Stunting and wasting (\% in children under 5) } \\
\text { - Unhealthy life years (\% of life expectancy) } \\
\text { - Deaths under } 60 \text { from non-commun. diseases (\%) } \\
\text { - Obesity (\% of adults with BMI > 30) } \\
\text { - Business impact of non-communicable diseases } \\
\text { - Business impact of communicable diseases }\end{array}$ & $\begin{array}{l}15 \\
42 \\
31 \\
78 \\
89 \\
32\end{array}$ & $\begin{array}{r}1.026 \\
0.411 \\
0.919 \\
-0.471 \\
-0.581 \\
0.798\end{array}$ & $\begin{array}{c}6.3 \\
12 \\
14.9 \\
23.0 \\
4.22 \\
6.27\end{array}$ & $\begin{array}{c}1.2 \\
8 \\
7.3 \\
1.1 \\
2.74 \\
3.13\end{array}$ & $\begin{array}{c}36.5 \\
66 \\
55.8 \\
42.8 \\
5.87 \\
6.90\end{array}$ \\
\hline $\begin{array}{l}\text { Well-being } \\
\text { - Stress (\% of respondents) } \\
\text { - Depression (\% of respondents) }\end{array}$ & $\begin{array}{l}59 \\
85\end{array}$ & $\begin{array}{l}-0.095 \\
-0.500\end{array}$ & $\begin{array}{l}32 \\
15\end{array}$ & $\begin{array}{l}8 \\
2\end{array}$ & $\begin{array}{l}69 \\
37\end{array}$ \\
\hline
\end{tabular}




\begin{tabular}{|c|c|c|c|c|c|}
\hline $\begin{array}{l}\text { Services } \\
\text { - Water, sanitation and hygiene (\% with access) } \\
\text { - Healthcare quality } \\
\text { - Healthcare accessibility }\end{array}$ & $\begin{array}{l}43 \\
90 \\
79\end{array}$ & $\begin{array}{l}0.718 \\
-0.842 \\
-0.588\end{array}$ & $\begin{array}{l}98.1 \\
3.08 \\
3.94\end{array}$ & $\begin{array}{l}31.1 \\
1.78 \\
2.41\end{array}$ & $\begin{array}{l}100.0 \\
6.75 \\
6.75\end{array}$ \\
\hline \multicolumn{6}{|l|}{ Pillar 3: Workforce and Employment } \\
\hline $\begin{array}{l}\text { Participation } \\
\text { - Labour force participation rate, age } 15-64(\%) \\
\text { - Labour force participation rate, age } 65+(\%) \\
\text { - Economic participation gender gap } \\
\text { - Unemployment rate }(\%) \\
\text { - Youth unemployment rate }(\%)\end{array}$ & $\begin{array}{c}- \\
- \\
60 \\
104 \\
102\end{array}$ & $\begin{array}{c}- \\
- \\
0.136 \\
-1.998 \\
-2.457\end{array}$ & $\begin{array}{c}- \\
- \\
0.660 \\
19.2 \\
42.5\end{array}$ & $\begin{array}{c}43.4 \\
1.6 \\
0.310 \\
0.3 \\
1.6\end{array}$ & $\begin{array}{c}90.6 \\
91.2 \\
0.839 \\
32.0 \\
48.2\end{array}$ \\
\hline $\begin{array}{l}\text { Talent } \\
\text { - Country capacity to attract talent } \\
\text { - Country capacity to retain talent } \\
\text { - Ease of finding skilled employees } \\
\text { - Pay related to productivity } \\
\text { - Capacity for innovation } \\
\text { - Index of Economic Complexity } \\
\text { - Firm level technology absorption } \\
\text { - Scientific and technical articles (per } 1000 \text { people) } \\
\text { - Median age of the working population }\end{array}$ & $\begin{array}{c}118 \\
121 \\
76 \\
100 \\
114 \\
34 \\
117 \\
34 \\
32\end{array}$ & $\begin{array}{c}-1.794 \\
-1.745 \\
-0.313 \\
-0.860 \\
-1.145 \\
0.552 \\
-1.534 \\
-0.231 \\
0.936\end{array}$ & $\begin{array}{c}1.59 \\
1.84 \\
3,77 \\
3.40 \\
2.79 \\
0.63 \\
3.72 \\
0.119 \\
39\end{array}$ & $\begin{array}{c}1.48 \\
1.81 \\
2.13 \\
2.37 \\
2.31 \\
-1.96 \\
3.17 \\
0.000 \\
28\end{array}$ & $\begin{array}{c}6.08 \\
5.97 \\
5.69 \\
5.25 \\
5.84 \\
2.37 \\
6.23 \\
1.242 \\
42\end{array}$ \\
\hline $\begin{array}{l}\text { Training } \\
\text { - Staff training } \\
\text { - Training services }\end{array}$ & $\begin{array}{l}119 \\
107\end{array}$ & $\begin{array}{r}-1.606 \\
-1.173\end{array}$ & $\begin{array}{l}3.01 \\
3.38\end{array}$ & $\begin{array}{l}2.51 \\
2.67\end{array}$ & $\begin{array}{l}5.57 \\
6.47\end{array}$ \\
\hline \multicolumn{6}{|l|}{ Pillar 4: Enabling Environment } \\
\hline $\begin{array}{l}\text { Infrastructure } \\
\text { - Mobile users (per } 100 \text { people) } \\
\text { - Internet users (per } 100 \text { people) } \\
\text { - Quality of domestic transport }\end{array}$ & $\begin{array}{l}34 \\
60 \\
86\end{array}$ & $\begin{array}{r}0.539 \\
-0.059 \\
-0.537\end{array}$ & $\begin{array}{c}125 \\
42 \\
4.00\end{array}$ & $\begin{array}{c}17 \\
1 \\
2.08\end{array}$ & $\begin{array}{c}191 \\
95 \\
6.51\end{array}$ \\
\hline $\begin{array}{l}\text { Collaboration } \\
\text { - State of cluster development } \\
\text { - Business and university R\&D collaboration }\end{array}$ & $\begin{array}{c}112 \\
91\end{array}$ & $\begin{array}{l}-1.304 \\
-0.659\end{array}$ & $\begin{array}{l}2.96 \\
3.19\end{array}$ & $\begin{array}{l}2.33 \\
2.11\end{array}$ & $\begin{array}{l}5.49 \\
5.84\end{array}$ \\
\hline $\begin{array}{l}\text { Legal framework } \\
\text { - Doing Business Index } \\
\text { - Social safety net protection } \\
\text { - Intellectual property protection and property } \\
\text { rights }\end{array}$ & $\begin{array}{c}68 \\
87 \\
106\end{array}$ & $\begin{array}{l}-0.117 \\
-0.708 \\
-1.042\end{array}$ & $\begin{array}{c}86 \\
3.01 \\
3.03\end{array}$ & $\begin{array}{c}1 \\
2.10 \\
1.62\end{array}$ & $\begin{array}{l}180 \\
6.26 \\
6.31\end{array}$ \\
\hline $\begin{array}{l}\text { Social mobility } \\
\text { - Social mobility }\end{array}$ & 117 & -1.479 & 3.05 & 2.78 & 6.36 \\
\hline
\end{tabular}

Source: Human Capital Report (2013). World Economic Forum, pp. 448-449.

The information from table 2 show that the state of the education pillar is relatively satisfactory in terms of access and attainment to education, while the key problem is the low quality of education. The pillar of health problems exist in terms of quality and accessibility of health services, then the impact of NCDs on business, the period of poor health throughout life, depression and obesity. The workforce pillar problems exist in terms of employment and unemployment size and the quality of the workforce, relationship towards talent, the volume of investment in staff training and quality training. Therefore, there are problems in almost all positions of the pillar of the workforce. The 
environment pillar assessments are better in terms of infrastructure, and they are worse in cooperation, the legal framework and social mobility.

Table 3 presents the information on education and employment of population in order to consider in more detail characteristics of human capital.

Table 3 Education and employment (2013)

\begin{tabular}{|l|c|c|}
\hline The population aged 15 and over by level of education \\
\hline Total & Number of residents & $\%$ \\
\hline No education & 6161584 & 100 \\
\hline Incomplete primary education & 164884 & 2,67 \\
\hline Primary education & 677499 & 10,9 \\
\hline Secondary education & 1279116 & 20,7 \\
\hline Higher education (VI-2) & 3015092 & 48,9 \\
\hline Higher education (VII-1) & 348335 & 10,6 \\
\hline The structure of employment by level of education & 652232 \\
\hline & Number of employees & $\%$ \\
\hline Total & 2310718 & 100 \\
\hline No education & 14507 & 0,6 \\
\hline Incomplete primary education & 122443 & 5,3 \\
\hline Primary education & 350376 & 15,2 \\
\hline Secondary education & 1304566 & 56,4 \\
\hline Higher education (VI-2) & 162680 & 7,0 \\
\hline Higher education (VII-1) & 356146 & 15,4 \\
\hline The structure of unemployment by level of education & $\%$ \\
\hline \multicolumn{2}{|c|}{774890} & 100 \\
\hline Total & Number of unemployed & 0,6 \\
\hline No education & 4649 & 2,2 \\
\hline Incomplete primary education & 17047 & 15,5 \\
\hline Primary education & 120108 & 64,1 \\
\hline Secondary education & 496704 & 6,2 \\
\hline Higher education (VI-2) & 48043 & 11,4 \\
\hline Higher education (VII-1) & 88337 & 69 \\
\hline Source Statistical Yearbor & \\
\hline
\end{tabular}

Source: Statistical Yearbook of the Republic of Serbia, (2014), p. 41, 66 \& 69.

The educational structure of the population in Serbia is unfavourable considering the fact that $1 / 3$ of the adult population over 15 are at the primary education level or below it, and it means that they don't have the necessary skills and competencies for participation in the labour market. Results from the 2011 Census indicate that 1,96\% of the population is illiterate. Very problematic is a low percentage of people who are with higher education which is $10,5 \%$ of the total population taking into consideration that highly educated people are of importance for the development of economy and society.

The structure of employment is dominated by people with secondary education and it is $56,4 \%$ of the total. There are a significant number of those at level of tertiary education and it is $22,5 \%$, while the number of those with primary education and lower is $21,2 \%$. Thus, it was confirmed by the international experience that employment of 
people increases with higher level of education. In our case, we still have a large number of employees with basic education which indicates a low level of development of the economy. People with primary and secondary education take a dominant place in the structure of unemployment and it is $64,1 \%$, and there are also a significant number of those with higher education and it is $17,6 \%$. A large share of people with higher and secondary education in the structure of unemployment shows deficit of competencies required for the work or the absence of effective reform of the education system, poor quality of education, education mismatch with the needs of employers and the labour market, but also it is the result of bad conducted transition and strong economic crisis in the country.

Serbia is among the countries in Europe that records the lowest values of the indicators of life expectancy. The value of this indicator for Serbia is 74 years, and it is lowered for five years compared to the average of the countries of the European Union. The health status of the Serbian population aged 18-64 was rated as good in $36,4 \%$ of cases according to the Health Survey in 2013, very good 26,8\%, solid 24,0\%, while poor in $10,8 \%$ of cases and very poor $2.0 \%$ (Matković, 2015, p. 147). These information points out the unsatisfactory state of health of the nation.

In accordance with the information in tables 1, 2, and 3 and the comments given we conclude that human capital in Serbia doesn't answer well enough to the economic and social needs, and that the level of development of human capital is low.

\section{Limitations of human capital development}

The basic factors of human capital are education and health. The value of human capital depends on the volume of investment in education and quality education. Whereas, the world experience shows that the quality of education is a more important factor than the volume of investment in education when it comes to the improvement of human capital, and greater investment in education doesn't guarantee a higher quality of education (Bokonjić, 2014, p. 17). There is also a strong link between health and improvement of human capital because healthy people can fully access to education or engage in the world of work or upgrade their skills and competencies and contribute to greater productivity. Human capital is created not only through formal education and training, but also through cooperation and socializing with other people where we come to the fore of social ties and norms or social capital. Societies, that are able to create a culture which the education is highly valued, will succeed significantly to increase human capital (Bokonjić, 2014, p. 3). Human capital is also affected by demographic trends and migration. The factors of human capital previously listed are the bottlenecks in the case of Serbia and are limiting development of this form of capital.

Author identifies the following limitations of human capital development in Serbia:

- $\quad$ Low GDP per capita and poor prospects for rapid economic growth;

- $\quad$ Low employment and high unemployment of the population;

- Deep poverty and social exclusion of the population;

- Nonfunctional market economy and inefficient labour market;

- Inadequate education system and poor educational policy; 
- $\quad$ Inadequate health care system;

- $\quad$ Bad attitude of the private sector towards human capital;

- Weak social capital;

- Negative demographic trends and the brain drain.

GDP per capita of Serbia was 5.908 dollars in 2013. The low level of GDP per capita implies the inability of the state to allocate significant funds for education. The share of Serbian government expenditure for education is $4,5 \%$ of GDP, while the recommendations of UNESCO is $6,0 \%$ of GDP. The problem is the low share of expenditure for higher education that is 0,85 of GDP, which is significantly lower than $3,0 \%$ of GDP as suggested by the Lisbon Agenda. Previously mentioned shows a bad position of education in Serbia at the scale of state and social priorities. Government expenditure in Serbia for health care is relatively satisfactory and it reaches $10 \%$ of GDP (Human Development Report, 2014, p. 189.). However, if we look at the absolute sizes of Serbian government expenditure for education and health, we recognize their multiple insufficiency in comparison with selected OECD countries, and it is a result of differences in the level of GDP. The Serbian government expenditures per capita for education is 277 dollars per year and 614 dollars for health, while the United Kingdom allocates 2.215 dollars and 3.679 dollars, Germany 2.249 dollars and 4.995 dollars, France 2.573 dollars and 4.988 dollars, respectively (Global Competitiveness Report 2014-2015, 2014, p. 402; Human Development Report, 2014, p. 188-194, the calculation of the author).

Serbia's economic growth forecasts, according to the World Bank and the International Monetary Fund, won't have exceeded 2,0\% per year for the next three years (World Economic Prospects, 2015, p. 67). Bleak prospects for dynamic economic growth say about the unattractiveness of private investment in education or training due to unprofitability. Special problematic is the trend of diminishing technologically demanding industries, which implies a reduction of human capital. The low rate of economic growth in Serbia is the result of bed investment environment and an unfavourable business climate, and above all it is a consequence of low competition, restrictive labour regulation, high taxes and contributions and corruption (Kuzmanović, 2014, p. 21).

Serbia has been troubled by problem of low employment and high unemployment. The employment rate was only $37,7 \%$ in 2013 . Human capital loses value when it isn't in use, or in the case of unemployment (Petrović, 2010, p. 117). There was a massive loss of human capital due to massive unemployment in Serbia, which was 775 thousand people or represented by unemployment rate - 22,1\% (Workforce Survey 2013, 2014, p. 10). It is particularly devastating impact of long-term unemployment on the value of human capital since it nullify the effects of investment in education and training of people. Long-term unemployment rate was $17,5 \%$ in 2013 , while the share of the longterm unemployed in the total number of the unemployed reached $76,0 \%$, which indicated the extent of the problem. Long-term unemployment leads to a loss of knowledge and experience, and thus reduce the opportunities for re-employment. Youth unemployment is also large and it amounted to $49,4 \%$ in 2013 , and it has resulted in significant reduction in human capital (The Second National Report about Social Inclusion and Poverty Reduction in the Republic of Serbia, 2014, p. 13, 129-130). 
The number of the poor in Serbia had increased from 470 thousand people in 2008 to 610 thousand in 2013 as a result of the tightening of the economic crisis in the country. The poverty rate was $6.1 \%$ in 2008 and it was 8,6\% in 2013 (Mijatović, 2014, p. 38). Atrisk-of-poverty rate was $24,6 \%$ in 2012 . The trend of increasing poverty corresponds with a decreasing in employment and rising unemployment. The level of material deprivation of the population in Serbia is very high. Material deprivation rate was 44,2\% in 2013, high material deprivation rate was $26,9 \%$ and extreme material deprivation rate was $14,2 \%$ (Matković, 2015, p. 40). The risk of poverty or social exclusion rate was $42,1 \%$ in 2013, which indicated that three million people in Serbia were at risk of poverty or social exclusion (Matković, 2015, p. 104). Social exclusion is very common with Roma, and the following community groups are also very vulnerable: refugees, internally displaced persons, persons with disabilities, youth, rural populations, women, and other. Poverty and social exclusion impede access to education, health and labour market, and thus they affect directly the reduction of human capital.

Labour market efficiency is low, and it is confirmed by an indicator of the efficiency of the labour market of the Global Competitiveness Index according to which Serbia recorded mark 3.9 and it took 119 place of 148 countries in the world in 2013. Defectiveness of the labour market expresses in terms of allocative inefficiency leads to loss of human capital. Human capital isn't used adequately because the deployment of the workforce isn't perform according to economic criteria, but rather on political or social ones, and it results in the reduction of human capital. The relationship between the productivity of labour and level of earnings is weak (Global Competitiveness Report 2014-2015, 2014, p. 335). Summing up, there is a situation of unclear relationships in terms of costs and benefits to individuals within the world of work so that the motivations for investing in education and acquiring job skills are lost. The dysfunctional market economy depends on previously mentioned problems. Links between quality and profit enterprises, or the quality of the workforce and the market position of the company are cut off by undeveloped integrated market; weak protection of competition, private property and contract; soft and political loans; widespread corruption; plentiful state aid and large public sector. Businessmen aren't stimulated to hiring the best workers in order their businesses survive and succeed, but they look for and crate number mechanisms of survival by themselves.

The quality of education in Serbia is unsatisfactory, and the situation is unenviable in the case of the secondary and high education, while the situation is better in primary education. The low quality of education is confirmed by indicator of quality of education system of the Global Competitiveness Index of the World Economic Forum according to which Serbia was 111 places out of 148 countries in the world in 2013. Education in Serbia focuses to the accumulation of knowledge of students rather than developing the ability of solving problems and applying knowledge. The poor quality of higher education is of concern, considering the importance of higher education in the promotion of human capital, competitiveness growth and economic development. One of the key reasons of the low quality of higher education is a system of education funding. The current system of financing of higher education institutions in Serbia that it is based on the number of enrolled students leads these institutions to quantity instead of the quality as the fundamental purpose of education. The quality of education in management is also very bed, and according to the indicator of the quality management of schools of 
the Global Competitiveness Index, Serbia is on the $114^{\text {th }}$ place out of 148 countries in the world.

Education isn't a market-oriented, and the links between educational institutions and businesses are weak. This results in surplus of some profiles with simultaneous deficit of other profiles. The situation is alarming in the case of secondary education. Due to the weak cooperation between domestic industry and educational institutions, a large number of people with secondary education can't find a job because they don't have the necessary competencies, knowledge, and skills. On the other hand, many employers, despite high unemployment, have difficulties in finding the adequate staff.

The efficiency of the education system is unsatisfactory. The dropout rate in primary school was 0,28 in the academic year 2012/2013, and secondary school it was $1,55 \%$ (Statistical Yearbook of the Republic of Serbia, 2014, p. 104). The average length of study at universities was 6,8 years in 2012 and it means that it was 2,3 years longer than it has been determined. Dispersal during education is present among the Rome and the rural population (Education Development Strategy in Serbia until 2020, 2012, p. 30).

Coverage of education is unsatisfactory. Coverage of primary education was $97,24 \%$ of the population in school year $2012 / 2013$, secondary education was $88,5 \%$, and higher education was 45,9\%. (Statistical Yearbook of the Republic of Serbia, 2014, p. 104). Serbia is one of the few countries of Europe, where secondary education isn't compulsory, and this results in low coverage of education. The Roma population is low involvement in education, and accessing to education is also difficult in the case of the rural population (Education Development Strategy in Serbia until 2020, 2012, p. 29-30).

Informal education is poorly developed in Serbia. Number of adults aged 25-65 which involve in the educational programs of the informal system is insufficient, and it was $16,5 \%$ in 2011 (41\% in the European Union). Educational programs don't focus on the development of the necessary competencies of the workforce. The quality of the educational services is unsatisfactory. The links between formal and informal education system are weak. Qualifications that acquired informally aren't recognized adequately in the formal education system and the labour market. Culture of lifelong learning is poorly affirmed in Serbia. The number of adults aged 25-65 involved in lifelong learning programs was 3,5\% in Serbia in 2013, while the recommended level was $15 \%$ in the European Union (The Second National Report about Social Inclusion and Poverty Reduction in the Republic of Serbia, 2014, p. 153).

Serbia's health care system characterizes the poor quality of services, inefficiency and inaccessibility. These are all problems which contribute to the poor health situation of the nation, and thereby reducing human capital. The structure of the dying population of Serbia makes preventable and premature mortality dominant. Specifically, the most people die from cardiovascular diseases, malignant diseases, accidents and injuries according to the Republican Bureau of Statistics of the Republic of Serbia, which are all diseases that can be prevented, and these diseases affect people in the most productive part of life (The Second National Report about Social Inclusion and Poverty Reduction in The Republic of Serbia, 2014, p. 18). This structure of dying indicates poor quality of the health system and bad attitude of the population towards the individual health, weak prevention and bad life habits. Inefficiency of health system comes as a result of redundancy, poor motivation of staff and poor management. Unavailability of health services is expressed in the case of the poor, rural population, people with disabilities 
and for certain ethnic groups it is a consequence of geographic, physical, financial and cultural constraints.

Employers have inadequate attitude towards human factor and therefore to the human capital, which is reflected in the dominant methods of employment, the absence of investment in training workers and poor treatment of workers. The most common method of employing workers in Serbia is by friends and relatives, and it amounted to $34,3 \%$ in 2011, followed by employing via job advertisements $25,2 \%$, through the National Employment Service 22,8\% and other methods of recruitment 13,8\% (Gijić, 2012, p. 123.). It is important to draw attention to the fact that employment in the private sector in a large extent is carried out also by friends, relatives and political ties. Companies aren't interested in investing in staff training. Employers see the training of workers as a liability and expense rather than an opportunity and investment for improvement of company performance. It is indicative that according to the indicator extent of staff training of the Global Competitiveness Index, Serbia occupied the 140 place out of 148 countries in the world in 2013. Indicator for cooperation between workers and employers puts Serbia on 144 place, and it points to poor attitude of employers and workers. Poor attitude of employers towards workers is reflected in the great exploitation of workers, low wages, avoiding the payment of salaries and contributions, unpaid overtime, disrespect of the employment contract, disrespect of the regulations on occupational safety, unethical quitting, mobbing, etc. Such an attitude of employers towards workers has resulted in a negative attitude of workers towards work, knowledge and working collective, and the final effect is a reduction in the quality of the workforce.

The low level of social capital in Serbia expressed in terms of a lack of confidence, poor social cohesion and an opportunism as socially desirable behaviour hampers increasing human capital (Golubović, 2014, p. 90). Good cooperation and high trust among community members increases the motivation for acquiring new knowledge and working skills (Blagojević, 2009, p. 8). Invest into the human capital is more costeffective in an environment of high trust (Džunić, 2011, p. 65). Good social capital makes human capital more effectively and more valuable when it comes to its contribution in increasing labour productivity and economic growth. The weak social capital in our case induces reduction of human capital and it lowers its effectiveness.

Serbia's population had decreased by 350 thousand people in the period 20022014. Population reduction was caused by a negative natural increase or migration which affect the development of human capital since they reduce the human base. Very problematic is the mass migration of high-quality personnel abroad so called brain drain, since it represents a loss of quality labour, but also the loss of significant funds that the state has invested in the development of people. The negative impact on the development of human capital has the deterioration of the age structure of the population. According to the Republic Statistical Office of Serbia share of Serbia' population older than 65 years was $21,6 \%$ higher than the share of the population younger than 15 years old in 2012, and the average age of the population was 42,2 years (Statistical Yearbook of the Republic of Serbia, 2014, p. 36-37). These all point to a narrowing base of human capital. 


\section{Critical review of the significance and impact of improving human capital on economic growth and development in Serbia}

Human capital is a key factor of economic growth and development (Petrović, 2010, p. 104). Improvement of human resources, i.e. knowledge and skills of people, is the key for increasing labour productivity and the competitiveness of the economy. The value of human capital reflects on the possibility of creating and supporting new technologies and it contributes to the technological development, meaning that it contributes to economic growth and development. Interdependence between the sector of education and scientific research sector is known. Highly educated workforce is a prerequisite for the transfer of new technologies from rich countries to less developed countries.

The positive impact of human capital in economic theory on the acceleration of economic growth is unambiguous. Experiences in the world show that countries that invest more in the education of people have a higher gross domestic product, faster and better economic growth, that come as results of growth of economic competitiveness. The situation is similar in the case of investing in the health of people considering that only healthy people can be really productive. The importance of human capital development in the modern era - the informational society - a society of knowledge, lies in the fact that each national economy and its competitive position in the globalized world are primarily determined by the quality of available human resources.

Highly developed human capital in addition to economic growth and development also contributes to social progress and political stability (Džunić, 2011, p. 62). Societies that are more educated function better than those whose individuals are less educated. The level of education is directly correlated with the level of crime in a society. High level of education of the population has resulted in lower levels of crime.

Human capital in Serbia, considering its low value, has a bad influence on the dynamic of economic growth, or it contributes to the slowdown of the economy. Economic growth forecasts of the World Bank and the International Monetary Fund for Serbia talk about bad prospects for boosting growth in this decade, and the background of the problem is the quality of the workforce as one of the key factors of low competitiveness of the Serbian economy. The lack of quality workforce and unfavourable structure of the labour force in Serbia hinder and impede economic development.

The contribution of human capital in Serbia to the growth and development of the economy is unsatisfactory. The mass of human capital in Serbia is an unused resource as a consequence of weak economic activity and high unemployment. Moreover, a significant part of human capital isn't used adequately due to the slow pace of economic reforms and disposal, and the example of this is a significant surplus of employees in the public sector where the effective working time lasts only 4,5 hours per day.

The Serbian economy has been in an economic crisis for six years that is a consequence of too high consumption compared to the volume of production, and all that is a consequence of the absence of economic reforms "transition" and low competitiveness of the economy. Bearing in mind that the competitive position of Serbian economy is largely determined by the quality of the workforce, there is a need for improving human capital. Insisting on the cheap workforce, which is a key factor of competitiveness of the 
domestic economy, is a fatal because there is no high-quality and inexpensive human resource. If we want to have quality workforce, we need abundant investment in people by the state and private sectors, as well as, creating the conditions in which individuals have the motivation and interest to invest in themselves. Each opposing tendencies will have negative long-term effects to the economy and society.

Improving human capital in Serbia is necessary to support the growth and development of the economy. The relevance of improving human capital in Serbia is determined by stage of economic development. In fact, Serbia's economy has been transiting from the development phase which is based on fundamental factors to the development phase which is based on increasing efficiency. This phase of development of the economy is the one which is dominantly conditioned by human capital. The efficiency driven economy sees its competitive advantage in investing in the improvement of human capital by the development of secondary and higher education.

Upcoming changes in the economic structure of Serbia, in the direction of growth of share of technologically demanding industries, can't get off the ground in practice without adjustments in the structure of the workforce or improving human capital. Those are mutually coupled processes where the growth and development of the whole economy and individual economic sectors and branches depend and condition the development in terms of the quality of complementary human resources. Development prospect of the economy imposes the needs and the direction of development of human capital. The development of human capital in Serbia requires a change in the educational structure of the population in favour of higher educated, the improvement of health status of the nation and the improvement of the skills of people in order to improve the quality of the workforce.

\section{Measures for the improvement of human capital}

Improving human capital implies a set of measures and activities to be undertaken at the level of the state, economy and society in order to improve the knowledge, abilities and skills of people in accordance to the needs and demands of growth and economic development. Improving human capital in Serbia, with regard to the needs of the economy for highly valuable human resource, and the identified and analysed limitations of human capital development, includes the following priorities:

- Improving the education system and educational development;

- Establishing the system of training and working practices;

- Improving the health care system;

- Increasing the employment of the working-able population;

- $\quad$ Removing the defect of the labour market;

- Improving the general economic environment;

- Promotion of social capital.

Improving the education system requires the expansion of the coverage of education, increasing the quality and efficiency of education. Expanding coverage of education implies greater availability of education for all social groups, and especially for the marginalized social groups. It requires reducing financial barriers for students 
at enrollment, increasing horizontal and vertical mobility between different levels of education and implementation of the concept of inclusive education. One of the important measures aimed at increasing coverage of education is compulsory secondary education Greater coverage of education also requires better informing students about educational opportunities, transparency and promotion of education. Improving the quality of education requires a change in the system of education financing, or introducing the model of education financing in accordance with output parameters - the number and quality of graduates. Improving the quality of educational services requires improving the quality of teachers, the introduction of modern methods of teaching and learning and modernizing the educational space. Growth efficiency of education requires reducing the burden of students, improving the organization of the teaching process, better communication of education institutions and students, greater collaboration of professors and students, career counselling, financial support of students and other. The implementation of these measures and activities requires government support in the form of increasing investment and education from the current $4,5 \%$ of GDP to $6 \%$.

Education is necessary to be adjusted for perspective of the development of economy and labour market demands. The focus must be put on higher education and the development of quality scientific personnel, followed by the development of managerial and entrepreneurial education. Achieving better integration between education and the labour market, or the compliance of offer and demand on the labour market, demands the greater involvement of employers in the educational process. Adjustments are necessary in terms of harmonization of educational profiles according to the needs of employers, the adoption of a national qualifications framework, the general harmonization of educational plans and programs according to the needs of the economy, and then conceiving enrolment policy to the real needs of the labour market.

The development of human capital in Serbia is connected with the application of the concept of lifelong learning. Education ceases to be time-limited, and it becomes a lifelong process, which should be promoted by the state. Improving informal education requires the establishment of an appropriate centre for education, improving the quality of teachers and better educational programs. The focus must be on retraining the unemployed, and it is especially young population.

Human resources are a key factor in the survival and the success of the companies in the modern age. Therefore, the employers have the interest to increase and improve this resource through training and working practices. Increasing private sector investment in training and working practices of employees requires state support in the form of financial incentives for entrepreneurs. There is a problem of efficiency and effectiveness of training, but also the problem of insufficient investment in training. Training of employees has insufficient quality, it is implemented sporadically and it isn't strategically justified, but it is made when some operational problem happens, and all these results in weak effects of training into improving competences of employees. Overcoming the lack of the above mentioned, requires improving the quality of training and practices through financial, institutional and logistical support of the government or strengthening the capacity of the private sector in the implementation of training and working practices.

Improving the health system involves a long-term process of increasing the quality, efficiency and availability of the system. One of the priorities of health system reform is to change the way health financing. Health financing must be oriented towards a patient 
because it is the best way which leads to an increasing efficiency and quality of health services. Health financing, which has been a dominant so far, is oriented towards the staff so it gets poor results. Disease prevention and promotion of healthy living are essential for improving the nation's health compared to the current poor healthcare system and poor health habits of the population. Increasing the accessibility of the health system requires better information about health rights and financing of health care of vulnerable social groups, with regard to poor knowledge and lack of health insurance are key factors of impeding access of the members of these groups to the health care system.

Increasing employment in Serbia is a priority of special relevance for improving human capital due to high unemployment. Human capital renews and increases through the work, and it loses and decreases due to economic inactivity and unemployment. High unemployment in Serbia is the consequence of negative trends of development and reform changes, or lack of development and regression in development trajectory as a result of the slowness, lack of transition and badly implemented reforms. In fact, high unemployment reflects the failure of transitional reforms. Unemployment also comes as a result of inadequate education system or the existence of a gap between the available and required knowledge and skills on the labour market. It is structural unemployment which can't be overcome in the short term, but it requires time.

Increasing employment and reducing unemployment in Serbia demands quality and dynamic economic growth or long-term growth, labour market reform, improving the education system and the employment system. Improvements of human capital are primarily connected to the development of the economy or creating a mass of highquality jobs and consequently a quality workforce through education and training.

Removing defects of labour market demands liberalization and institutional upgrading of the labour market. It is known that the adequate allocation of labour resources, in accordance with market principles, is one of the conditions of improving the quality of the workforce because it gives the true motivation. The favourable effects in term of increasing and human capital development are realized in condition of the free labour market, because then all market participants receive only what they deserve. The efficient labour market conditions gradation in quality which generates the true motivation.

Improving the economic environment in Serbia is necessary due to the poor economic situation in the country and the fact that a good economic and investment environment makes investments into human capital development worthwhile. Good economic climate and perspective make human capital more valuable. Improvement of the investment environment and business climate in Serbia requires macroeconomic stability, better protection of private and intellectual property, intensifying competition, reduction of administrative constraints, developing financial markets, construction and modernization of infrastructure, reduction of corruption and so on.

Improvement of social capital in Serbia as a way of enhancing human capital includes the process of democratization, building and strengthening the state institutions, the development of civil society, strengthening the rule of law, running the economy, establishing a more equitable distribution of gains and reform of the social protection system, and it is a long process of development of trust and strengthening social cohesion. Improvement of social capital in particular requires the reduction of poverty and social exclusion because they fundamentally undermine the human integrity, and thereby reinforcing the distrust thus they generate all kinds of social problems. 


\section{Conclusion}

The level of human capital development in Serbia is low which is confirmed by the human capital index of the World Economic Forum according to which Serbia recorded a rating of $-0,343$ and stood on 85 position in the ranking of 122 countries in the world. Looking at the key components of human capital - education, health, labour and socioeconomic environment we see unsatisfactory ratings. The situation of human capital in Serbia is very bad in the case of labour and socioeconomic environment, while it is somewhat better in the case of education and health. Important information about the nature of human capital in Serbia provides an overview of the educational structure of the population as well as the educational structure of the sectors of employment and unemployment. The analysed facts indicate that the educational structure of the population is unfavourable, the quality education is poor, and that the competence of the great number of working-able population is unsuitable for inclusion in the labour market.

The low level of human capital development in Serbia is the result of numerous general economic and deeper systematic constraints. The long economic crisis and the absence of effective market reforms have resulted in deterioration and reduction of human capital. Obstacles to the development of human capital in Serbia can be summarized as follows: the low level of GDP per capita; the expected slow pace of economic growth in the future; low employment rate; high long-term unemployment; high youth unemployment; widespread poverty and social exclusion; poor educational policies, inadequate education, health and social system; non-functional market economy, defective labour market, weak social cohesion; disturbed value system and so on.

High-quality workforce forms the basis of competitive advantage of the most developed countries compared to less developed countries and developing countries. A quality workforce is a key condition for increasing the nation's wealth in a world affected by the process of globalization, transition, scientific and technological revolution. Countries that invest more in education and health have a higher gross domestic product per capita than those countries that are unable or unwilling to do so. Serbia is one of the developing countries and a factor of the poor quality workforce is the key one that contributes to the maintenance of such awkward position. It can be concluded that the importance of a valuable workforce for of Serbian economy is outstanding and it is especially important if the state wants to improve its competitive position, and thus the development position, increasing the wealth of the nation, citizens' standard of living and improving working conditions.

Improving human capital is a complex and long-term process which requires an increasing the educational level of the population, development of competencies of employees and potentially employable persons in accordance with the needs of economic development and growth, and improvement of the health status of the nation, or raising the level of human capital. Improvements in the case of Serbia are expedient in terms of the goals of education, the education system, health system, completing the forming of the training system and working practices, creating the conditions for greater employment of the population, increasing the efficiency of the labour market and the establishment of a functional market economy, improvement of the economic environment and the improvement of social capital. 


\section{References}

Anketa o radnoj snazi 2013, (2014). Republički zavod za statistiku, Beograd.

Blagojević, S., \& Marinić, I. Š. (2009). Razvojne funkcije humanog i socijalnog kapitala u savremenim uslovima. Ekonomika, 55(6), 1-9.

Bokonjić, B. (2014). Unapređenje obrazovanja kao činilac ekonomskog razvoja, Fakultet za ekonomiju, finansije i administraciju, Beograd.

Cicea, C., Cvijanović, D. V., \& Subić, J. (2008). The Health Care Systems in European Union and International Comparison. Ekonomika, 54(1-2), 9-19.

Čikić, J. (2014). Promene u obrazovnoj strukturi u post-socijalističkoj tranzicijisrpsko iskustvo. Teme-Časopis za Društvene Nauke, (03), 1037-1056.

Drugi nacionalni izveštaj o socijalnom uključivanju $i$ smanjenju siromaštva $u$ Republici Srbiji, (2014). Vlada Republike Srbije, Beograd.

Džunić, M. (2011). Društvene determinante akumulacije ljudskog kapitala, Ekonomske teme, 59 (1), 59-70.

Gijić, N., Đuretić, G., \& Lilić, V. (2012). Metodi zapošljavanja radne snage u Srbiji. Ekonomika, 58(3), 120-129.

Global Competitiveness Report 2013-2014, (2013). World Economic Forum, Geneva.

Global Competitiveness Report 2014-2015, (2014). World Economic Forum, Geneva.

Global Economic Prospects, (2015). World Bank, Washington.

Golubović, N., Džunić, M., Marinković, S. (2014). A Comparative Analysis of Social Capital in the Western Balkan Countries, Industrija, 42(2), 71-92.

Human Capital Report, (2013). World Economic Forum, Geneva.

Human Development Report, (2014). UNDR, New York.

Krstić, B., Backović, N., Džunić, M., (2012). Education as a determinant of developing knowledge economy and national competitiveness - benchmarking study of Balkan countries“, International conference on Economics and Regional Development - Eurobrand 2012, 245-256.

Krstić, B., Stanojević, J., (2013). Human capital development as a determinant of Agricultural Competitiveness in Serbia, in: Improving the competitiveness of enterprises and national economies - factors and strategies (Ed. Krstić Bojan and Zbignew Paszek), University of Nis - Faculty of Economics, Andrzej Frycz Modrzewski Krakow University, 207-222.

Kuzmanović, M., Sanfey, P., (2014). Diagnosing Growth Contraints in Southeastern Europe: The Case of Serbia, Working Paper, No. 167, EBRD, London.

Matković, G., Krstić, G., Mijatović, B., (2015), Prihodi i uslovi života 2013, Republički zavod za statistiku, Beograd.

Mijatović, B. (2014). Siromaštvo u Srbiji 2011, 2012. i 2013. godine, Vlada Republike Srbije, Beograd.

Petrović, P. (2010). Uticaj ljudskih resursa na privredni rast i razvoj Srbije, Ekonomski horizonti, 12 (1), 103-119. 
Statistički godišnjak RS, (2014). Republički zavod za statistiku, Beograd.

Strategija razvoja obrazovanja u Srbiji do 2020. godine, (2012). Sl. glasnik RS, br. 107/2012, Vlada Republike Srbije, Beograd.

Zubović, J. (2007). Investing in Human Resources, Economic Analysis, 40(1-2), 1-5. 